\title{
"Politics of History" as a Threat to the Internal Peace in Ukraine ${ }^{1}$
}

\author{
prof. Dieter SEGERT
}

\begin{abstract}
This article examines the role of the historical narratives and of the "politics of history" in the domestic politics of Ukraine. It compares the role of emotions within nationalistic and socialist ideological discourses about history. It gives an overview on different elements of national and regional identity in the country. It enquires mainly differences in selfidentification, practical language use, pluralistic religious orientations, and media use. Some of the heterogeneities emerged in the past during industrialization of Soviet Ukraine. It suggests that differentiation is not objectively given but produced and exploited by political contestation for power. A main field of political polarization consists in the politics of history. It debates the outcomes of the laws on decommunization and the responsibility both of intellectuals and politicians for the nationalization politics. At the end the article stresses the possible alternative outcomes of history politics on the stability of the Ukraine as a nation state.
\end{abstract}

\section{Keywords}

post-socialism and nationalism, ethnic fragmentation of Ukraine, politics of history, decommunization

"Politics of history" plays a prominent role within the whole post-socialist Eastern Europe. Ukraine is only one example for that. But the latter is a country in which the debates on history have an especially high impact on recent politics. The author of this article is interested in to better understand why different interpretations of Soviet history play a central role within the Ukrainian politics after 2014. What is going on with the identity differences in political contestation? And he looks for alternative solutions: Is there also a way out of the fierce struggle about historic narratives? The paper is based mainly on discussion from the East European area studies literature in Germany and Austria and own analyses of recent politics in Ukraine. ${ }^{2}$

\footnotetext{
1 The author would like to thank the two anonymous reviewers for their proposals to ameliorate the paper.

2 The author has based his assumptions by experiences as a researcher on the Ukrainian party system during the Orange revolution (SEGERT, Dieter: Political parties in Ukraine since the 'Orange Revolution', in: Ukraine
} 


\section{On the Link between Communist and Nationalist Ideologies}

The interesting political science question consists in why historical debates have played such a central role throughout Eastern Europe in the post-socialist development after 1989: A lively historical-political debate was a characteristic feature of almost every post-socialist development. The various political camps have each advanced pronounced positions on the history of the country. In this regard, the assessment of the state socialist period plays a central role. In many cases, such as in Bulgaria, the opposing positions in this dispute were almost identical with the two major political camps of that time: on the one hand, with the political successors of the Communist state party, on the other hand, with the "antiCommunist" opposition. ${ }^{3}$ In other cases, as in Croatia, a nationalist reinterpretation of the history of the country, especially of the history since the Second World War, has become the legitimizing basis of the political authority. ${ }^{4}$

This shaping of the public discourse by historical-political topics is, firstly, a legacy of the previous political order. In state socialism, the authority of the ruling communists was mainly legitimized by an ideology. ${ }^{5}$ The core of this ideology was the interpretation of its own history as part of a world-changing movement of the working class. The communism as the great goal was interpreted as an irresistible result of the laws of history. However, the politics has to intervene into the course of history by suppressing other ways of its interpretation. That was the apology of censorship in the former society. Because the communist interpretation of history was regarded as a worthy truth, it could not be allowed to question it. In this respect, the post-socialist debate about history is possible to interpret as a justified attempt to overturn that one truth.

on its way to Europe. Interim results of the Orange Revolution, BESTERS-DILGER, Juliane (Ed.), Frankfurt a. M. 2009) and by intense study of media reports from Ukraine since 2013. He used as well opinion polls by research institutes in Ukraine. To his latest publication on the issue see his interviews and online publications in English and German, (SEGERT, Dieter: It is not possible to integrate Ukraine against Russia into Europe, Interview with Natalia Laas, online: http://historians.in.ua/index.php/intervyu/1223-dieter-segert-it-is-not-possible-to-integrateukraine-against-russia-into-europe (Downloaded 15 July 2014.); SEGERT, Dieter: Bittere Schokolade - Kann der Staatszerfall der Ukraine noch aufgehalten werden? [bitter chocolate - Is it possible to stop still the decay of Ukraine as a state?], in: UA-Analysen 133, 2014, the German Agency for Civic Education) as well as two publications at EASTBLOG since 2016: EASTBLOG: Blog of the East European Studies Group at the University Vienna, online: http://eastblog.univie.ac.at/.).

3 MEZNIK, Michael: Nostalgie und Amnesie und die geschichtliche Auseinandersetzung im Postsozialismus [Nostalgia, amnesia, and the historic debate during post-Socialism], in: Gegenwart der Vergangenheit. Die politische Aktualität historischer Erinnerung in Mitteleuropa, PÄNKE, Julian et al. (Ed.), Berlin 2007, 31-38.

4 RADONIC, Ljiljana: Krieg um die Erinnerung - Kroatische Vergangenheitspolitik zwischen Revisionismus und europäischen Standards [Struggle for memory - Croatian politics of memory between revisionism and European benchmark], Frankfurt a. M. 2010.

5 The state socialist power relations were not only characterized by a dual antagonistic relationship between the ruling elite and population, as presented in the totalitarian model, but it was tripartite: elite, sub-elite (service class) and population. Just for the broad service class, the ideological legitimation of the system was important. See e.g. BRIE, Michael: Staatssozialistische Länder Europas im Vergleich. Alternative Herrschaftsstrategien und divergente Typen [European State socialist countries in comparison. Alternative strategies of power holding and divergent types], in: Einheit als Privileg: Vergleichende Perspektiven auf die Transformation Ostdeutschlands, Frankfurt a. M, Campus 1996, 39-104; SEGERT, Dieter: Intelligenz und Macht - Der Beitrag der intellektuellen Dienstklasse zu Stabilität und Wandel in der DDR [Intelligentsia and power - Contribution of the intellectual service class to stability and change in GDR], in: Ordnung und Wandel als Herausforderungen für Staat und Gesellschaft, Opladen 2009, 129-147. 
However, the protagonists of such an anti-communist struggle led it partly also with an ideological fervor, which reminded of those former communist propaganda. It has to be assumed therefore that in this debate was more than a reasonable criticism of an onesidedness of the former rulers. It was additionally a result of the emerging nationalistic interpretation of politics. The core of ethnic-nationalistic ideology consists in the delineation of the own community against all others. Every form of this kind of nationalism in history was characterized by an enthusiastic exaggeration of its own nation, the celebration of its uniqueness and of the superiority over other nations. Due to the ideological vacuum after the decay of communist ideology there was an overall rise of nationalist identity in the countries of the region. Especially widespread was nationalism in the former multiethnic federal states like Soviet Union and Yugoslavia.

Great emotionality characterizes both communist and nationalistic discourses. The followers of these movements usually regard the criticism of one's own cause as "treason". Intellectuals, philosophers, writers, journalists, priests and historians, were the main carrier of these discourses. ${ }^{6}$ Their fantasies and narratives were the fuel of many conflicts in the past and in the present. The intellectuals deepen by their narratives still the political dangers caused by these discourses. This dispute about the "Self and the Others" is particularly intense, because even at the beginning of a national awakening movement, the identity of the community is uncertain and controversial. This was also the case in Ukraine after its national independence.

\section{One, Two or Still More Ukraines?}

The basic problem in the area of the polity is that there can be no democracy without a clear national identity. The membership of a political community, of the state population in the context of a clearly defined territory, is a basic condition for the possibility of political competition in accordance with clearly defined rules. Only when all members of a national community feel that they clearly belong to this community, they can develop the necessary loyalty to it.

On closer examination of the situation in Ukraine and the identities existing there, in particular in the journalistic discourse, the image of the "two Ukraines" becomes striking. ${ }^{8}$ However, whether there are two or more different communities is unclear and will be the topic of the further examinations. The ethnic self-definition, language use, pluralistic religious orientations, and media use are the main points of the following analyze of the homogeneity of Ukraine.

6 Concerning the emergence of nationalism, see i.e. the nation theory of Miroslav Hroch (HROCH, Miroslav: Die Vorkämpfer der nationalen Bewegung bei den kleinen Völkern Europas: Eine vergl. Analyse zur gesellschaftlichen Schichtung der patriotischen Gruppen [Pioneers of national movements among the small people of Europe: A comparison of the layer of the patriotic groups], Praha 1968.) What concerns communism you can find many intellectuals as carrier of communist utopia even in the period of the "classic socialism" (a term of Janos Kornai, i.e. in time of Stalin).

7 RUSTOW, Dankward: Transitions to Democracy. Toward a Dynamic Model, in: Comparative Politics 1, 1960, 1-2, 337-360. Rustow stresses the "national unity as the sole background condition".

8 RIABCHUK, Mykola: Ukraine: One State, Two Countries?, in: Eurozine, 2002, online: http://www.eurozine.com/ articles/2002-09-16-riabchuk-en.html (Downloaded 6 May 2016). 
The data commonly used for the ethnic composition of Ukraine are from the census of 2001. According to this census, 17.3 percent of the respondents classified themselves as Russians and 77.8 percent as Ukrainians. ${ }^{9}$ This self-assessment concerning the own ethnic identity is an approach that was already the practice in the Soviet Union. ${ }^{10}$ Every adult had to assign to a particular nationality. This self-assignment was not checked by any external examination. The self-description was not identical to the maternal or paternal lineage, which of course may differ from each other.

One other criterion for ethnic classification could of course be the daily use of a certain language. This increases the number of "Russian Ukrainians" - measured by the number of people who state Russian as their mother tongue. In 2001, 34 percent reported Russian and 64 percent Ukrainian as their common everyday language. From survey data, we know also that there is a group using both Ukrainian and Russian at home. Over time, there were changes in the practical use of language: in 199437 percent of respondents stated that they would use Russian only, 33 percent Ukrainian only and 29 percent would use both languages are available. ${ }^{11}$ In 2005, the ratios then were were 35, 40 and just over 20 percent. $^{12}$

The language is, unlike the term "mother tongue" suggests, not only passed in the family, but also spread and secured through the institution of the school. In this regard, there had been contradictory trends in Soviet Ukraine: in the 1920s, the Ukrainian language became more widespread under the policy of "korenizatsiya", i.e. the "rootage" of the Soviet power within the indigenous population. The politics of "korenizasiya" has included both the support for the use of native language (Ukrainian) and the selection of native people for the political elite of the Soviet Ukraine (this has applied less or not at all to the territory of Western Ukraine, which at that time belonged to Poland and Romania). At a later period, in the years after 1945, the Soviet authorities promoted Russian language and culture in whole Soviet Ukraine. There was a growing proportion of students attending Russianspeaking schools. According to Kappeler, the Ukrainian language lost ground especially in the universities. Additionally, due to the industrialization and urbanization the share of the Russian-speaking population in the cities increased..$^{13}$

After 1991, the Ukrainian became the only state language. The schools promoted it too. While in 1991 the proportion of schools in which Ukrainian and others in which Russian was taught was about equal, these figures changed until 2005 to 78 percent Ukrainian- and 21 percent Russian-speaking schools. ${ }^{14}$

9 Ukraine-Analysen 19/2007/, p. 12 ff. Ukraine-Analysen will be abbreviated later on in the paper as "UA-Analysen".

10 ARMBORST, Kerstin. Ablösung von der Sowjetunion: Die Emigrationsbewegungen der Juden und Deutschen vor 1987 [Dissolution from the Soviet Union: emigrations of Jews and Germans]. Muenster 2001, 19.

11 The rest then were users of other languages such as Hungarian or Romanian.

12 A survey from 2008 by the Razumkov Centre shows the situation as follows: 44 percent speak Ukrainian, 26 percent Russian and 29 percent both languages. (UA-Analysen 106, 11) In 2014 the data shows the following ratio of language use: 43:31:25 percent (UA-Analysen 152, 15).

13 KAPPELER, Andreas: Kleine Geschichte der Ukraine [Short history of Ukraine], Munich 2009, 190 et sqq., 230 et sqq., 238, 240.

14 The trend in the recent years is going into the same direction. See as well JANMAAT, Jan. Nation Building in the Post-Soviet Ukraine. Educational policy and the response of the Russian-speaking population, Utrecht-Amsterdam, Royal Dutch Geographical Society, Germen, 2000. 
Another question is whether these figures give a real picture of language practices. Brubaker has stressed that "many of those who report their native language as Ukrainian prefer to speak Russian in everyday life". ${ }^{15}$ Even the nationalizing state would be more interested in demonstrating "the steady success of its language policies" than "capturing the actual figures in linguistic behavior". ${ }^{16}$

In this development, there are large regional differences additionally. While in the west, in the L'viv region, Ukrainian was taught in 99 percent cent of schools, in Odessa it was only in 65 percent, in Dnipropetrovsk 78 percent, in Donetsk 29 percent, and in the Crimea 5 percent. In Chernivtsi and Transcarpathia, the share of Ukrainian was lower than in Western Ukraine (about 80 percent), the share of Russian as high as in "Galicia", while other languages were taught to a larger percentage. ${ }^{17}$

To a third point, the church membership of different groups of the population. In Ukraine general, it did not play the same prominent role as it did in the disintegration process of Yugoslavia. Ethnic differentiation and church membership are transverse to each other. There are some regional priorities of the various Orthodox churches of Ukraine. The Unitarian (Greek Catholic) Church, together with the Ukrainian Autocephalous Orthodox Church has most of their supporters in Western Ukraine. The Ukrainian Orthodox Church (Moscow Patriarchate) together with its breakaway faction the Ukrainian Orthodox Church (Kyiv Patriarchate) has their most followers in the Center and the East of Ukraine. ${ }^{18}$ Yet, despite the dispute among themselves, these churches are still less opposed to each other than were the Croatian Catholic Church or the Serbian Orthodox Church in the Yugoslav disintegration process. However, as emphasized by Kappeler, the church differentiation is a "disintegrating element" of the Ukrainian nation-building process. The attempts to unite these churches were unsuccessful so far. ${ }^{19}$ Moreover, in the recent crisis the churches supported different sides. Nevertheless, church membership does not seem to reinforce ethnic differences within the country. ${ }^{20}$

To a last point, the use of media. There are Ukrainian and Russian media, of which TV stations that broadcast countrywide are of particular importance. In view of the propaganda offensive of the Russian TV and partial military confrontation in Donbass ${ }^{21}$, it is revealing to look at the

15 BRUBAKER, Rogers: Nationalizing states revisited: projects and processes of nationalization in post-Soviet states, in: Ethnic and Racial Studies 34, 2011, 11, 1801.

16 Ibidem, quoting DAVE, Bhavna: Kazakhstan: Ethnicity, Language, and Power, New York 2007.

17 UA Analysen 19, 2007, 15.

18 There is survey data from April 2014 on the membership of the various churches in different parts of the country (UA-analysis 137, 23). In the centre, 45 percent of the respondents regard themselves as belonging to the Orthodox churches of the Kiev or Moscow Patriarchate; in the south the share is 24 percent and in the west 37 percent. In the west, 2 percent, which is the highest share of all regions, state that they belong to the Autocephalous Orthodox Church. There was no question on the membership of the Unitarian Church.

19 KAPPELER, Kleine Geschichte..., 273.

20 Whether this situation is changing recently is not clear. At least, there are some recent complaints from the side of the Ukrainian Orthodox Church (Moscow Patriarchate) about violence against and occupation of church buildings by nationalistic groups in Western Ukraine. See NÖK: Nachrichtendienst Östliche Kirchen. no. 11/16, 2016, 17 March 2016, Part B, Universität Münster (Germany), NÖK noek@uni-muenster.de.

21 I use the Russian form of the geographical term because it is in German media most often used, in Ukrainian it would be "Donbas". 
results of a survey from December 2014 on the use of media by the Ukrainian population. On the question if Russian TV channels are watched at all, 5 percent in the west responded "regularly", 20 percent "from time to time", but 75 percent "not at all". In the center, the figures were only slightly different. In the south the number of those watching on a regular basis Russian TV was 9 percent and of the irregular viewer 24 percent. In the East (without Donbass) the respective figures were 9 and 33 percent, In Donbass alone 24 and 58 percent. ${ }^{22}$ Regarding confidence in the Russian television there was even more pronounced difference between the regions: while in the west there were only 8 percent who had at least partial confidence, in Donbass there were 20.5 percent who had full confidence and 66.6 percent who had at least partial confidence. In other regions, the shares, taken together, were as follows: in the center 15 percent, in the south 29 percent, and in the East (Donbass not included) 61 percent. ${ }^{23}$

The mentioned data from different areas show clearly that the identities of the Ukrainian population vary across different regions of the country. This diversity, however, do not substantiate a "bifurcation" of the country. The image of the "two Ukraines" is obviously an oversimplification of the existing diversity of identities. In addition, they are not only produced by differences in culture. One reason for the disparities stems from economic and social developments in the Soviet era. The industrialization and urbanization of the Soviet Union was associated with population movements across the borders of the Soviet republics. There was an influx of people to the hotspots of industrialization from rural regions of Ukraine but there were also huge number of them coming from outside.

In particular, this applies to the Eastern areas of the country, where new factories or mines were founded. In addition, there were marriages, which were concluded not only within the ethnic groups. Unfortunately, the standard works of historians (such as those of A. Kappeler ${ }^{24}$ ) do not contain accurate data on these marriages or demographic currents caused by Soviet industrialization. However, it can be assumed that these processes led to important shifts in the ethnic composition of the population of Ukraine. Overall, it is likely that in the industrialization areas the proportion of Russians and other non-ethnic Ukrainians increased and - probably - therefore intense kinship ties with people in other Soviet republics (nowadays: in other nation-states) developed. It is likely that such social ties have been further strengthened by the workers' migration from Ukraine to Russia after 1991. The recovery of economy of Ukraine started much later than in Russia.

In order to conclude this paragraph: the conflictive identities of Ukrainians in different parts

22 See the survey Mass media and the confidence in Ukrainian and Russian Mass Media (зМІ та довіра до українських і російських 3MI), KIIS, online: http://www.kiis.com.ua/?lang=eng\&cat=reports\&id=425\&page=2 (Downloaded 20 February 2015), especially the table 4. Yet in the summer 2015, the picture seemed to have clearly changed. A poll of "Media sapiens" from that time had the following results concerning use of Russian TV (or, to be more precisely, it was asked for the use of news information from Russian channels): There was no clear difference between the regions. In the West 2 percent indicated that they saw it every day, 11 percent several times a week, in the East it was 3 vs. 9 percent. The validity of the both polls is not yet clear for me.

23 See the survey Mass media and the confidence in Ukrainian and Russian Mass Media (ЗМІ та довіра до українських і російських 3MI), KIIS, online: http://www.kiis.com.ua/?lang=eng\&cat=reports\&id=425\&page=2 (Downloaded 16 February 2015), especially the tables 4 and 14.

24 KAPPELER, Andreas: Rußland als Vielvölkerreich. Entstehung, Geschichte, Zerfall [Russia as multiethnic empire. Formation, change, decay], Munich 2008. 
of the country emerged at different times and by very different reasons. Nevertheless, these differences are not objectively given. Their rise or decline depends on political mobilization mainly.

\section{National Identities Shaped by Political Mobilization}

Ethnic differences are open to political mobilization. The democratic contestation comprises lot of opportunities for its reinforcement: Parties have played the ethnic card in the elections, especially since the early 2000s.

"The regionally based pluralism can be also exploited for electoral strategy reasons. This became increasingly apparent since the early 2000s and led to a polarization of the political landscape, as values and identities were utilized by the political parties in order to legitimize their particular interests." 25

Parties, which in Ukraine are often not much more than only clientelistic networks and form around regional oligarchs, had mobilized voters especially according to their local or regional affiliation. The parties were devices for the formation of super-regional divisions. The "Party of Regions" - which was based on the "Donetsk clan", had obtained a strong base in the Eastern and Southern parts of the country, the "Orange camp" ("Our Ukraine" and BJUT) had been the strongest force in the West and in the Center. In the election campaigns, cultural issues such as language or historic interpretations partly played a prominent role. The politics of memory - the play with historic narratives- will be subject of later discussion. At this chapter, I will discuss the language politics of the parties.

One of the key issues of that ethnic and cultural mobilization since 2010 was the claim raised by the "Party of Regions" and the KPU for the recognition of Russian as a second state language. This claim was already raised earlier, namely by Kuchma in the first presidential campaign in 1994. However, in the fifteen years afterwards it has played no important role. In the run-up to the parliamentary elections in August 2012, a language law was adopted which recognized and promoted Russian alongside seventeen other regional and minority languages as a regional language. ${ }^{26}$

The language question played again an inglorious role in the first weeks after the fall of the Yanukovych government in late February 2014, when the right-wing party "Svoboda" introduced a motion in parliament for the repeal of the law from 2012. Although this decision, due to pressure from EU politicians, was not signed at that time by the incumbent president and thus not enforced, it apparently still caused political damage in a situation of uncertainty of the population in the East and South of the country. ${ }^{27}$

25 STYKOW, Petra: Innenpolitische Gründe der Ukraine Krise, Gleichzeitige Demokratisierung und Staatsbildung als Überforderung [Domestic reasons for the crisis of Ukraine. Simultaneous processes of democratization and state building as excessive demand, in: Osteuropa 64, 2014, 5-6, 48.

26 On the respective law, see the article written by Guttke and Rank in Ukraine-Analysen 106, 2012, 11-15. Russian language can be used officially at provincial, district and local level, where the proportion of the Russian-speaking population reaches 10 percent, according to official census data. However, the law did not make the Russian language a second state language as it was promised originally by the PR in its election campaign.

27 And it was misused by Russian propaganda, mainly in the case of the annexation of Crimea in March. In the present the language question is not a main concern for Ukrainian citizens irrespective of their regional affiliation. A poll conducted by the KIIS from July 2016 shows that only in the opinion of one percent of all polled the lan- 
A main reason for the caused political damage was the general political uncertainty after the ouster of Yanukovych. The next problematic step was the building of the transitional government on 27 February. Instead of building a government of national reconciliation with representatives from all camps, a transitional government emerged exclusively built by political groups and parties from the West and the Centre of Ukraine. The occupation of public buildings in the East of the country in the days after it was partly a reaction of this exclusion.

Unlike in the post-Yugoslav disintegration process the ethnic tensions in Ukraine did not lead to armed conflict until early 2014. The crisis of the state in winter 2013/14, however, turned into open violence, which was significantly fueled by the Yanukovych government in January and February. After the escape and dismissal of Yanukovych, a period of instability followed. The ruling party "Party of Regions", which in 2012 still had 30 percent of the votes and together with independent candidates held a majority of seats in the parliament, collapsed almost completely in the first weeks of 2014.

After the Maidan in Kiev and the supporting protest movement against Yanukovych especially in the West and in the Center, an anti-Maidan-movement emerged in the East and the South. It led to the occupation of administrative buildings. The initiative for the occupation-movement came probably from political and economic forces of the Eastern Ukraine, who wanted to get a hold on the new government in Kyiv. Among them were the oligarchs from this region like Akhmetov. The old network of the ousted president (Yanukovych) certainly played a role too. When the Crimea seceded after a referendum and with Russian support from the Ukraine, the new government deployed troops against the protests in the east and launched a so-called "anti-terrorist operation" (ATO). ${ }^{28}$ Supported by Russian interference in various ways, it came to an armed conflict, which focused especially on the Donbass (Donetsk and Luhansk areas). Whether it is a civil war or Russian occupation was much disputed in the media. In my opinion, it was a mix of both phenomena.

Since then, the ethno-nationalist mobilization has gained a new dynamic. Although the conflict could not be described as an open civil war, there is still a mobilization of allegiance of various population groups to different cultural and political identities, which has the potential for such a civil war.

Russia's intervention is not the only cause of the crisis. The intervention was successfully mainly due to the existence of internal dividing lines within the population and the elites of Ukraine.

\section{"Politics of History" and the Power of Intellectual Fantasies}

This dispute on historical narratives is particularly intense in insecure nations, because at the beginning of a national awakening movement, the community identity is uncertain and controversial. This was also the case in Ukraine after its national independence in 1991. To recap again: While in the referendum in March 199175 percent of the population still

guage question is a major concern. See online: http://www.kiis.com.ua/?lang=rus\&cat=news\&id=641\&page=7 (Downloaded 21 March 2017).

28 It is in my opinion surely not an appropriate name for an action aimed to re-unite the country. The former president (Yanukovych) has named the last armed action against the protesters at Euro-Maidan as well "ATO". 
voted in favor of remaining in a renewed federation, at the end of the same year, in a second referendum 90 percent voted for an independent Ukraine.

The two main issues of the "politics of history" since then were the Second World War, and the Soviet history and its symbols. However, these issues are intermingled with each other too. The Second World War was for various reasons an ideal arena for such a historical debate: the late socialist Soviet Union under Brezhnev has commemorated it as the "Great Patriotic War", thus making it a core element of their ideological legitimation of power. Its rituals and commemorations were present throughout Soviet everyday life. ${ }^{29}$

For the population the Second World War was also the arena for the development of Ukraine in its present boundaries (apart from the Crimea). It was not until then that the Western Ukraine (including the areas of Chernivtsi and Transcarpathia) was becoming a part of the country. In particular, in the three areas of "Eastern Galicia" there had been a strong resistance movement against the integration into the Soviet Union. It has led deep traces in social memory of this part of the country. During the liberalization of perestroika, the Rukh movement revived the historical memory. Intellectuals produced its narratives and emotional symbols in many ways.

The new political class of independent Ukraine tried, similar to Tuđman in Croatia, to reconcile the two antagonistic historical narratives of the late Soviet and of national movement in the Western Ukraine. The presidents of the new state have set different focal points. A step towards reconciliation was to award the fighters of the Ukrainian Insurgent Army the official status of war veterans in 1993 by president Kravchuk. Yet the reassessment of the OUN and UPA as "new 'positive heroes' and avant-garde of the Ukrainian (sacrificial) nation" remained controversial. ${ }^{30}$ The attempt to keep quiet about the anti-Semitism and nationalistically motivated violence by the UPA against non-ethnic Ukrainians has proved especially controversial.

President Kuchma was the next agent of the debate after Leonid Kravchuk. He continued in the attempt to incorporate different elements of Ukrainian national identity, including the Cossack myth as well as a "modified Ukrainian national myth of the Great Patriotic War". ${ }^{31}$ Under President Yushchenko, the focus of historical politics shifted to an open confrontation with the Soviet history. For this purpose, he initiated the Ukrainian Institute of National Memory. ${ }^{32}$ An important project was the interpretation of the famine in the early 1930 s as an ethnically motivated crime, the so-called "Holodomor". In the very term of "Holodomor", there is an onomatopoeic reminder of the "Holocaust". This was a conscious move. The aim was to transfer the pan-European consensus of a strict condemnation of the German crimes against European Jews to the politically induced famine of 1932-33 in the Soviet Union. ${ }^{33}$

29 JILGE, Wilfried: Nationalukrainischer Befreiungskampf. Die Umwertung des Zweiten Weltkriegs in der Ukraine [Nationalist Ukrainian struggle for liberation. Reassessment of WWII in Ukraine], in: Osteuropa 58, 2008, 6, 167-186.

30 Ibidem, 170.

31 Ibidem, 173.

32 MYESHKOV, Dmytro: Politics of history in Ukraine since the change of government in the spring of 2014, in: Civic Education and Democratisation in the Eastern Partnership Countries, SEGERT, Dieter (Ed.), Bonn 2016, 144.

33 In the early 1930s, about three to three and a half million people died in the Soviet Ukraine on the con-se- 
On the initiative of Yushchenko, a law in 2006 classified that famine as genocide against the Ukrainian people and its denial as a criminal act. The previous debate in parliament was controversial. The "Party of Regions" did not deny the responsibility of the Soviet leadership for the famine, but rejected the genocide thesis, because that, in their view, would split the country.

Notwithstanding of this objection it cannot be ignored that all parties engaged in this debate. Both the "Orange" and the "Blue" 34 camp represented power-political goals in this respect. The "Party of Regions" intended to weaken the public support for the president. O. Turchynov as representative of the Orange camp denounced those members of parliament who opposed the genocide thesis as acting against the "'true' patriotism ". ${ }^{35}$ Maybe Yushchenko as an intellectual believed in the possibility of a "state-sponsored nation-building ". ${ }^{36}$ Yet his next step has cast serious problems for it. The president declared some prominent members of the Ukrainian Insurgent Army as official "Heroes of Ukraine": The first was, Roman Shukhevych in 2007, followed by Stefan Bandera in 2010. ${ }^{37}$ The aim of these actions was to characterize the OUN and UPA as a national, anti-totalitarian freedom movement and to exculpate them from the charge of anti-Jewish and anti-Polish policy. This move contributed significantly to political polarization within the country. ${ }^{38}$

This move can better be understood within a broader anti-Soviet "politics of history". The strategic goal of the presidential play with history was to present the Soviet period of Ukraine "as a period of time, which is foreign to the 'true' national history and which is thus separate from the own history". ${ }^{39}$ This aimed to a cultural separation from Russia.

Other words: Yushchenko's policy was a step towards growing ethnic nationalism. It tries to close the ranks and to produce a common identity by referring to the external other. Especially young nation states that have emerged by splitting from a previous single state try to demarcate themselves from the previously dominant state: Czechoslovakia did it via Austria, Norway via Sweden, and Finland via Russia.

However, the broader population in the Eastern and Southern Ukraine did not meet this cultural separation from Russia with enthusiasm. The symbols of the fight for Ukrainian independence after 1918 and in the time between the wars - Bandera and the UPA /OUN - were regarded as allies of the German aggressor. Even though that this evaluation has produced by Soviet propaganda, it works. Just the fact that important parts of population believed in this assessment is important. If the unity of the nation is considered as target of this policy, it has to be said that this goal was not achieved. Rather the opposite was the

quences of the forced collectivization and industrialization policy of the Soviet leadership. (JILGE, Wilfried: Geschichtspolitik in der Ukraine (am Beispiel des Holodomor) [Politics of memory in Ukraine /at the example of Holodomor/], in: Aus Politik und Zeitgeschichte 57, 2007, 8-9, 1.)

34 "Our Ukraine" and "Fatherland" at one side, the "Party of Regions" on the other.

35 The president and his camp intend to serve the unification of the nation. Jilge argued that the commemoration would actually have accomplished this task. (JILGE, Wilfried: Geschichtspolitik in der Ukraine ..., 3.). The development of Ukraine since then, however, casts in my opinion doubt on his interpretation.

36 Ibidem.

37 Both titles were revoked again by court rulings under the presidency of V. Yanukovych in 2011.

38 LIEBICH, Andre - MYSHLOVSKA, Oksana: Bandera. Memoralization and commoration, in: Nationalities Papers 42, 2014, 5, 750-770.

39 JILGE, Nationalukrainischer..., 183. 
case: the existing differences in the perceptions of Ukraine's history were further increased. The "Party of the Regions" and its President Yanukovych tried to utilize the controversial reactions to the politics of history of the Orange camp for securing their own power base. The withdrawal of the hero titles that were awarded to the representatives of Ukrainian Independence Army was a step in this direction. Another was the introduction of Russian as a second official regional language by a law in 2012.

The next turn of historical politics came with the second Maidan protest movement (the so-called "Euromaidan") from fall 2013 onwards. Jilge evaluated it more positively. ${ }^{40}$ The aim on the respective politics of Maidan activists would have been a political mobilization through the commemoration of the Zaporozhe Cossack tradition and the national poet Shevchenko. The respective activities wanted to update both traditions as a "source of an authentic national self-consciousness", and to demonstrate "that the Ukrainians have a separate history and that they are a vibrant nation that no longer wants to be determined by others". ${ }^{41}$

A second argument of Jilge was that the traditions of the UPA /OUN would not have been dominant on the second Maidan. His central argument is that the slogan used by the UPA: "Slava Ukraina! Herojam Slava!" (Glory to Ukraine! Glory to the Heroes!) would have been removed from its historical connotations. Protesters at the Maidan would use the slogan neutral.

However, in my view, this interpretation has serious deficiencies. ${ }^{42}$ For the political impact of historical symbols, it is not only important how the immediate actors understood it. The effect on the audience of this action is also important, and this is far greater when conveyed through television.

Concerning these slogans, the wider audience in Ukraine regards it different. The population in the west perceives it differently than those in the East and South. Whether the perception of such UPA slogans as "fascist" by large sections of the population in the East and South was result of Soviet and Russian propaganda does not matter in this regard. Only the effect is politically important. For the Ukrainian situation of a society that is divided in the evaluation of the contemporary history of their own country the promotion of the traditions of a part of the population against the perceived traditions of another part, is certainly problematic. ${ }^{43}$

In a survey of the Ukrainian "Fund of Democratic Initiatives" by the end of 2014/beginning

40 JILGE, Wilfried: Geschichtspolitik auf dem Majdan. Politische Emanzipation und nationale Selbstvergewisserung [Politics of memory at Maidan. Political emancipation and national process of coming to terms with itself], in: Osteuropa 64, 5-6, 2014, 239-257.

41 Ibidem, 253

42 Given the Russian propaganda that denounced the entire second Maidan and the government that appointed after the fall of V. Yanukovych as a "fascist putsch", I could understand this effort though. From the perspective of the impact of politics and political symbols, however, it is one-sided and wrong. Apart from this political aspect, also other observers perceived the activities of the West Ukrainian nationalists differently than Jilge did (see RYABCHUK, Anastasiya: Right Revolution? Hopes and Perils of the Euromaidan Protests in Ukraine, in: Debatte. Journal of Contemporary Central and Eastern Europe 22, 2014, 1, 132).

43 In addition, the previous attempt of historical-political exculpation of the right-wing traditions of the Western Ukrainian UPA/OUN is problematic not only from a Russian propaganda perspective. The rejection of symbols of the Ukrainian Insurgent Army has also good reasons for itself from the perspective of the much-vaunted European values. 
of 2015 on the topic "What unites and what separates the Ukrainians" these differences in the perception of historical events become visible. "In relation to the establishment of the OUN in 1929 and the UPA in 1942 the situation is very much different [namely highly differentiated by regions, D.S.]. There is a positive assessment of the OUN and the UPA in the 'orange' regions of Ukraine (Volhynia, Galicia, Transcarpathia, Bukovina, Kiev, Center, Podolia, Polesia), while a negative assessment prevails in the regions of the Southeast (Donbass, Zaporozhe, the regions of the Black Sea, and the area Kharkiv and Poltava). " 44

President Poroshenko plays no neutral role in this current historical-political controversy. His decision to declare the 14 October, which is also the founding day of the UPA ${ }^{45}$, Ukrainian army holiday ("Day of Defender of the Fatherland"), may have an equally problematic effect for overcoming the historical-political division. Thus, he replaced the "Day of the founding of the Soviet Army", which in many of the former Soviet republics, including Ukraine, was formerly celebrated on 28 February as a day of their own army. This kind of "politics of history" has further divided Ukraine, and it will not be easy after the end of the military struggle in the East of the country to overcome the divisions created by history politics.

The next turn came with the laws on decommunization in April 2015, and the following decisions of the parliament in February and May 2016. In February 2016, the "parliament approved the scrapping of 175 names of towns, villages, and districts across the country and replaced them with non-Soviet alternatives". ${ }^{46}$ There was a lot of criticism by European institutions and by Western scholars. ${ }^{47}$ The most dangerous damage to the political stability of the state though stems from the fact that the decision of the parliament intervened into the daily life of groups of citizens without asking them on their opinion. As Baumgartner wrote:

"But the decommunization plan is fiercely opposed by many Ukrainians - particularly those in the southern and eastern parts of the country, many of them ethnic Russians - who believe the country and its politicians should spend their time on more important issues

44 Online: http://www.dif.org.ua/ua/publications/press-relizy/sho-obednue-ta-rozednue-ukrainciv.htm (Downloaded 25 February 2015; own translation from Russian - D.S.) The overall assessment of the second "Maidan" in 2015 is very different in the various regions of Ukraine: While 90 per cent of respondents in Western Ukraine supported the protests on the Maidan and elsewhere against the government, in the South there were only 20 per cent and in the East only close to one-third. On this argument see also the report Umfragen: Zwei Monate Proteste [opinion poll: 2 month of protest], Bundeszentrale für Politische Bildung, Dossier Ukraine, 2, online: http:// www.bpb.de/internationales/europa/ukraine/178019/umfragen-zwei-monate-proteste-in-der-ukraine (Downloaded 5 February 2015). Similar different were the assessments of the "ATO" in different parts of the Ukraine; the opinion that it is part of a "civil war" was strong in the East (38 percent), weak in the West (14 percent) - see: Attitude of population to media, propaganda and media-reforms during the conflict time, Media Sapiens, online: http://osvita.mediasapiens.ua/monitoring/in_english/survey_attitude_of_population_to_media_propaganda_and_mediareforms_during_the_conflict_time/ (Downloaded 16 February 2016).

45 It is however, also traditionally celebrated as the Day of the Cossacks. The demand to declare 14 October the Day of the Army was a long-standing demand of Western Ukrainian nationalists.

46 BAUMGARTNER, Pete: Ukraine's Decommunization Gets Boost As 175 Towns, Villages Renamed, Radio Free Europe/Radio Liberty, online: http://www.rferl.org/content/ukraine-decommunization-boost-175-towns-renamed/27532794.html (Downloaded 4 February 2016).

47 See, among others, the Open letter from experts and scholars on Ukraine with the appeal to president Poroshenko not to sign the laws on decommunization, online: http://krytyka.com/en/articles/open-letter-scholars-andexperts-ukraine-re-so-called-anti-communist-law (Downloaded 26 May 2016). 


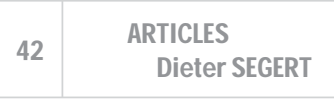

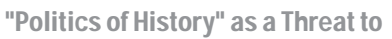

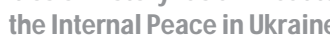

than replacing communist toponyms or who don't want to erase everything associated with the Soviet era."

Especially due to the fact that the regional and local identities play an important role for the identity building of the citizens of Ukraine, the centralized renaming of their home towns without asking the respective population on their opinion is not a decision that foster the reconciliation of different regional identities. About necessary changes in the "politics of history" and especially on the decommunization laws the Ukrainian historian A. Portnov pointed out: "Ukraine should come up with a special symbolic policy for the territories. [...] some change should occur. I do not think that the overall change in the Soviet street names were the best solution." 48

\section{Conclusion}

To sum up, intellectuals are inventing the narratives that are the content of a "politics of history". Politicians, historians, journalists and artists are leading minorities. They are the key players in this field. However, the "politics of history" is not just a playground of cultural and political elites. It leaves its traces on a majority of civil society by means of mass media or via the school as an institution. The invented historical narratives are able to influence the behavior of large sections of the population too. A certain consensus on the interpretation of central historical events is a prerequisite for a stable legitimacy of the common state. In this respect, in the field of "politics of history" difficult tasks arise for the further transformation of Ukraine, which need to be tackled. Alternative outcomes are possible: either to deepen the divergent interpretations of the recent history or to foster consent on it. Especially the politicians are able to support or to hinder this process by their decisions.

The Ukraine as a nation state is still fragile. There are different and overlapping regional identities. If nation is result of cultural construction than intellectuals are in charge to foster reconciliation. They should be more cautious by using their narratives and nationalistic fantasies. The aim of healing the wounds that were inflicted to each other by the struggle for power since February 2014 would request more listening to each other. The re-integration of Donbass after a future end of the military struggle is not possible without being open to different identities of this part of population.

No doubt, each serious narrative about history of one or another side has its good reason. However, it is not a good idea for the political class of Ukraine to facilitate only the narrative of one part of the population about their history at the expense of the historic narrative of others.

48 Compare the interview of the Ukrainian historian A. Portnov for the Polish NGO Krytyka Poliyczna: "Jak Ukraina może wrócić na Donbas?" (12 February, 2016), online: http://m.krytykapolityczna.pl/artykuly/ukraina/20160211/ portnow-jak-ukraina-moze-wrocic-na-donbas (Downloaded 15 February 2016). He answered for the question what should change in politics of history, especially concerning decommunization laws: "Ukraine should come up with a special symbolic policy for the territories. It is difficult to determine the details, but some change should occur. I do not think that the overall change in the Soviet street names were the best solution." 


\section{References}

ARMBORST, Kerstin: Ablösung von der Sowjetunion: Die Emigrationsbewegungen der Juden und Deutschen vor 1987 [Dissolution from the Soviet Union: emigrations of Jews and Germans], Muenster 2001.

Attitude of population to media, propaganda and media-reforms during the conflict time, Media Sapiens, online: http://osvita.mediasapiens.ua/monitoring/in_english/survey_attitude_of_population_to_media_propaganda_and_mediareforms_during_the_conflict_ time/ (Downloaded 16 February 2016).

BAUMGARTNER, Pete: Ukraine's Decommunization Gets Boost As 175 Towns, Villages Renamed, Radio Free Europe/Radio Liberty, online: http://www.rferl.org/content/ukrainedecommunization-boost-175-towns-renamed/27532794.html (4 February 2016).

BRIE, Michael: Staatssozialistische Länder Europas im Vergleich. Alternative Herrschaftsstrategien und divergente Typen [European State socialist countries in comparison. Alternative strategies of power holding and divergent types], in: Einheit als Privileg: Vergleichende Perspektiven auf die Transformation Ostdeutschlands, edited by Helmut Wiesenthal, Frankfurt a. M. 1996, 39-104.

BRUBAKER, Rogers: Nationalizing states revisited: projects and processes of nationalization in post-Soviet states, in: Ethnic and Racial Studies 34, 2011, 11, 1785-1814.

DAVE, Bhavna: Kazakhstan: Ethnicity, Language, and Power, New York 2007.

EASTBLOG: Blog of the East European Studies Group at the University Vienna, online: http://eastblog.univie.ac.at/.

Fond Děmokratični iniciativi im. Il'ka Kučeriva [Ilko Kucheriv - Democratic Initiatives Foundation], online: http://www.dif.org.ua/ua/publications/press-relizy/sho-obednue-tarozednue-ukrainciv.htm (Downloaded 25 February 2015; own translation from Russian - D.S.)

HROCH, Miroslav: Die Vorkämpfer der nationalen Bewegung bei den kleinen Völkern Europas: Eine vergl. Analyse zur gesellschaftlichen Schichtung der patriotischen Gruppen [Pioneers of national movements among the small people of Europe: A comparison of the layer of the patriotic groups], Prague 1968.

JANMAAT, Jan G.: Nation Building in the Post-Soviet Ukraine. Educational policy and the response of the Russian-speaking population, Utrecht-Amsterdam 2000.

JILGE, Wilfried: Geschichtspolitik in der Ukraine (am Beispiel des Holodomor) [Politics of memory in Ukraine /at the example of Holodomor/], in: Aus Politik und Zeitgeschichte 57, 2007, 8-9, 24-30.

JILGE, Wilfried: Nationalukrainischer Befreiungskampf. Die Umwertung des Zweiten Weltkriegs in der Ukraine [Nationalist Ukrainian struggle for liberation. Reassessment of WWII in Ukraine], in: Osteuropa 58, 2008, 6, 167-186.

JILGE, Wilfried: Geschichtspolitik auf dem Majdan. Politische Emanzipation und nationale Selbstvergewisserung [Politics of memory at Maidan. Political emancipation and national process of coming to terms with itself], in: Osteuropa 64, 5-6, 2014, 239-257.

KAPPELER, Andreas: Rußland als Vielvölkerreich. Entstehung, Geschichte, Zerfall [Russia as multiethnic empire. Formation, change, decay], Munich 2008.

KAPPELER, Andreas: Kleine Geschichte der Ukraine [Short history of Ukraine], Munich 2009. 
Krytyka Poliyczna: „Jak Ukraina może wrócić na Donbas?” (12 February, 2016), online: http://m.krytykapolityczna.pl/artykuly/ukraina/20160211/portnow-jak-ukraina-mozewrocic-na-donbas (Downloaded 15 February 2016).

LIEBICH, Andre - MYSHLOVSKA, Oksana: Bandera. Memoralization and commoration, in: Nationalities Papers 42, 2014, 5, 750-770.

Mass media and the confidence in Ukrainian and Russian Mass Media (ЗМІ та довіра до українських і російських 3MI), KIIS, online: http://www.kiis.com.ua/?lang=eng\&cat=reports\&id $=425 \&$ page $=2$

(Downloaded 16 February 2015).

MEZNIK, Michael: Nostalgie und Amnesie und die geschichtliche Auseinandersetzung im Postsozialismus [Nostalgia, amnesia, and the historic debate during post-Socialism], in: Gegenwart der Vergangenheit. Die politische Aktualität historischer Erinnerung in Mitteleuropa, PÄNKE, Julian et al. (Ed.), Berlin 2007, 31-38.

MYESHKOV, Dmytro: Politics of history in Ukraine since the change of government in the spring of 2014, in: Civic Education and Democratisation in the Eastern Partnership Countries, SEGERT, Dieter (Ed.), Bonn 2016, 141-150.

NÖK: Nachrichtendienst Östliche Kirchen. Universität Münster (Germany), NÖK noek@ uni-muenster.de.

Open letter from experts and scholars on Ukraine, online: http://krytyka.com/en/articles/ open-letter-scholars-and-experts-ukraine-re-so-called-anti-communist-law (Downloaded 26 May 2016).

RADONIC, Ljiljana: Krieg um die Erinnerung - Kroatische Vergangenheitspolitik zwischen Revisionismus und europäischen Standards [Struggle for memory - Croatian politics of memory between revisionism and European benchmark], Frankfurt a. M. 2010.

RIABCHUK, Mykola: Ukraine: One State, Two Countries?, in: Eurozine, 2002, online: http:// www.eurozine.com/articles/2002-09-16-riabchuk-en.html (Downloaded 6 May 2016).

RUSTOW, Dankward: Transitions to Democracy. Toward a Dynamic Model, in: Comparative Politics 1, 1970, 1-2, 337-360.

RYABCHUK, Anastasiya: Right Revolution? Hopes and Perils of the Euromaidan Protests in Ukraine, in: Debatte. Journal of Contemporary Central and Eastern Europe 22, 2014, 1 , 127-134.

SEGERT, Dieter: Intelligenz und Macht - Der Beitrag der intellektuellen Dienstklasse zu Stabilität und Wandel in der DDR [Intelligentsia and power - Contribution of the intellectual service class to stability and change in GDR], in: Ordnung und Wandel als Herausforderungen für Staat und Gesellschaft, LORENZ, Astrid - REUTTER, Werner (Eds.), 2009, 129-147.

SEGERT, Dieter: Political parties in Ukraine since the 'Orange Revolution', in: Ukraine on its way to Europe. Interim results of the Orange Revolution, BESTERS-DILGER, Juliane (Ed.), Frankfurt n. M. 2009, 45-59.

SEGERT, Dieter: It is not possible to integrate Ukraine against Russia into Europe, Interview with Natalia Laas, 2014, online: http://historians.in.ua/index.php/intervyu/1223-dietersegert-it-is-not-possible-to-integrate-ukraine-against-russia-into-europe (Downloaded 15 July 2014).

SEGERT, Dieter: Bittere Schokolade - Kann der Staatszerfall der Ukraine noch aufgehalten 
werden? [bitter chocolate - Is it possible to stop still the decay of Ukraine as a state?], in: UA-Analysen 133, 2014, the German Agency for Civic Education, online: http://www.bpb. de/internationales/europa/ukraine/185495/kommentar-bittere-schokolade (Downloaded 21 March 2017).

STYKOW, Petra: Innenpolitische Gründe der Ukraine Krise, Gleichzeitige Demokratisierung und Staatsbildung als Überforderung [Domestic reasons for the crisis of Ukraine. Simultaneous processes of democratization and state building as excessive demand, in: Osteuropa 64, 2014, 5-6, 41-60.

UA-Analysen (Ukraine-Analysen): Country studies of the research institute on Eastern Europe at the University Bremen and the German Association of East European Studies, for Ukraine published since 2006.

Umfragen: Zwei Monate Proteste [opinion poll: 2 month of protest], Bundeszentrale für Politische Bildung, Dossier Ukraine, 2, online: http://www.bpb.de/internationales/europa/ ukraine/178019/umfragen-zwei-monate-proteste-in-der-ukraine (Downloaded 5 February 2015).

\section{Author}

Univ.-Prof. Dr. Dieter Segert

Institut für Politikwissenschaft, Universität Wien

Institute of Political Science, University of Vienna

Universitätsstr. 7, 1010 Wien, Austria

dieter.segert@univie.ac.at 